\title{
パリトシンの起源は鞭毛藻か 渦鞭毛藻からパリトキシン類縁体を発見
}

ハワイには古来より“リム・マケ・オ・ハナ”の伝説 があった. ハナ（地名）の猛毒な海藻という意味で，、 ウイ島のハナの生息地は固い秘密とされ，その場所を侵 す者には災いがあると言い伝えられてきた，、ワイ大学 でシガテラ (熱帯, 亜熱帯地方の珊瑚礁海域で頻発する 低死亡率の魚類食中毒）を研究していた A. H. Banner 教授と P. Helfrich 博士は, この有毒海藻がシガテラ毒 の起源かもしれないと考光て興味を持ち，1961 年に生 息場所を突き止めた：その結果，この生物は海藻ではな く腔腸動物スナギンチャクの1種P Palythoa toxica（パ リトアトキシカ)であることが判明した。 また，採集に 向かった一行に対して，災いを恐れた住民たちが中止を
勧めたが，聞き入れずに採集を終えてオアフ島に戻って みると, 八ワイ大学海洋生物研究所の主研究棟が原因不 明の火災で消失していた．伝説のと拉りにたたりが実現 したと恐れられたエピソードとして有名である。これが 世界で最も複雑で猛毒な天然物とされたパリトキンン $\left(\mathrm{C}_{129} \mathrm{H}_{233} \mathrm{~N}_{3} \mathrm{O}_{54}\right)$ 発見のきっかけである. その後のハワ イ大学 Moore 教授, 名古屋大学平田教授らによる構造 決定 ${ }^{(1)}$ やハーバード大学岸教授による全合成 ${ }^{(2)}$ な゙は化 学の世界ではあまりに有名な話である。

一方, 同じくシガテラを研究していた筆者の一人 (T. Y.) は, 洞鞭毛藻 Gambierdiscus toxicus がシガテ ラ原因毒のシガトキシンやパリトキシンをさらに上回る

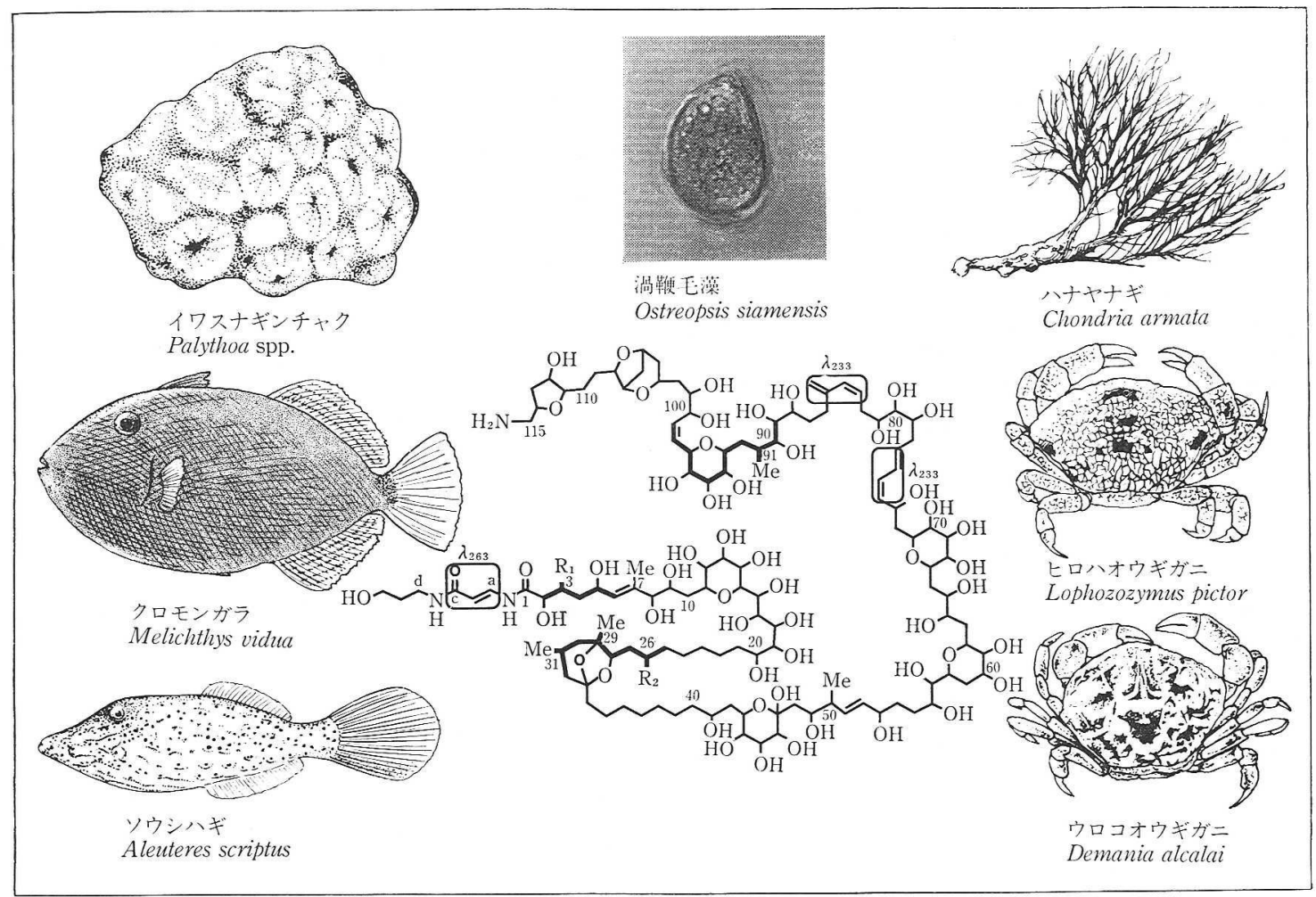

図 1 ロパリトキシンとオストレオシンDの構造とその含有生物

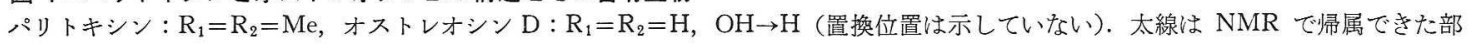
分, 四角は UV 発色団を示す. 
巨大・猛毒なマイトトキシン $\left(\mathrm{C}_{164} \mathrm{H}_{226} \mathrm{O}_{68} \mathrm{~S}_{2} \mathrm{Na}_{2}\right)$ を生 産し，食物連鎖を通じて魚類が毒を蓄積し，毒化してい く過程を証明していた(3)。この発見をきっかけに，海産 食中毒，たとえば，フグ毒，下痢性貝毒などの食物連鎖 による毒化機構を次々と明らかにした。 また，シガテラ 研究の一環として, 数多くの海洋微細藻の毒性スクリー ニングを行ない, オカダ酸を生産する Prorocetrum li$m a$ など多くの有毒微細藻を発見した. その中の一つに 底性渦鞭毛藻 Ostreopsis siamens：s があった。 O.siamensis は形態学的に G. toxicus と近縁種で, 海藻に付 着生育し，毒化地域によっては G. toxicus より優先種 である場合さえある．O. siamensis の生産する有毒成分 は毒性の強さや薬理学的性質がシガテラ関連毒とは異な ることからオストレオシンと命名し，その化学的性状解 明を試みた。

1991 年に鹿児島大学井上晃夫教授が沖縄県阿嘉島で 採取した O. siamensis を供与していただき，構造研究を 開始した．当初は精製が難航したが，徐々にその性質が 明らかとなっていくにつれて, クロマト挙動から「パリ トキシンかもしれない」と考孚ることもあったが，そん な幸運なことはないだろうと半信半疑であった。 また， 最終精製の前段階で ESI MS を測定したところ，2 価, 3 価の多種イオンが検出され, ペプチドの可能性も考光 られた. 実際, 加水分解物のアミノ酸分析ではセリンが 検出された. NMR ではペプチドではなくポリエーテル 化合物に似た多酸素化合物の特徵を示していたので混乱 を招いた。

その後, ようやく主成分オストレオシン Dの精製に成 功し, $0.2 \% \mathrm{CD}_{3} \mathrm{COOD} / \mathrm{D}_{2} \mathrm{O}$ 中の測定で初めてきれいな NMR スペクトルを得ることができた. その結果, オス トレオシン Dがパリトキシンの類縁体であることが判明 した. MS スペクトルから，オストレオシン D の整数 分子量は 2,633 であり, パリトキシンより 44 マスユニ ット小さいことが判明した. この值はメチル基 2 個, 水酸基 1 個がプロトンに置換された值に相当した. 600 $\mathrm{MHz}$ で測定したスペクトルでもシグナルの重なりが激 しく，水酸基の置換位置は特定できなかったが,メチル 基の置換位置は確定でき，オストレオシン $\mathrm{D}$ は $3,26-$ ビスデメチルデオキシパリトキシンであることが明らか
となった(4) (図 1).

パリトキシンとその類縁体は, 腔腸動物の他にも, 魚 類のソウシハギ, クロモンガラ, ヒロハオウギガニ, コ ブウロコオウギガニ, 紅藻ハナヤナギなどのかなり広範 囲の海洋生物に分布する(5) (図 1). しかし, 含量の変動 が大きいため，その起源に関して多くの議論があった。 ハワイ大学の Moore はVibrio 属の細菌にパリトキシ ン様の毒を検出したと述べているが，実験的証拠はまっ たく示されていない:( ${ }^{(6)}$. 今回の研究結果は, 食物連鎖最 下層の渦鞭毛藻からパリトキシン類縁体を単離し，パリ トキシンが食物連鎖または共生微生物を通して高位の生 物に移行する可能性を初めて実証したものである. しか しながら，海洋生物に見いだされるパリトキシンがすべ て O. siamensis 由来であるとはまだ断定でさない. パリ トアなどの腔腸動物には Zooxanthella 属の渦鞭毛藻が 共生しているが， O. siamensis が共生しているか否かは 明らかでない. 中村らは, 海産のヒラムシに共生する Zooxanthella からパリトキシンを思わせる巨大な有毒 成分ゾーザンテラトキシン $\left(\mathrm{C}_{140} \mathrm{H}_{232} \mathrm{NO}_{57} \mathrm{SNa}\right)$ を単離 している(7). パリトアの共生渦鞭毛藻のパリトキシン生 産性に興味が持たれる、いずれにせよ，筆者らの研究成 果は, パリトキシンの起源の一つを確定したのみなら ず, O.siamensis の培養によって，この複雑な化合物の 生合成経路の解明が可能になったことを示しており， ハ

リトキシン研究に新たな局面を拓いたと考えている.

1) (a) R. E. Moore \& G. J. Bartolini : J. Am. Chem. Soc., 103, 2491 (1981) ; (b) D. Uemura, K. Ueda \& Y. Hirata: Tetrahedron Lett., 22, 2781 (1981).

2) R. W. Armstrong, J.-M. Beau, S. H. Cheon, W. J. Christ H. Fujioka, W.-H. Ham, L.D. Hawkins, H. Jin, H. Kang, Y.Kishi, M. J. Martinelli, W.W. McWhorter, Jr., M. Mizuno, M. Nakata, A. E.Stutz, F.X. Talamas, M. Taniguchi, J. A. Tino, K. Ueda, J. Uenishi, J. B. Whitez \& M. Yonaga : J. Am. Chem. Soc., 111, 7530 (1988).

3)（a ）安元 健：化学と生物, 10, 369 (1992); (b) 安元 健, 村田道雄 : 化学と生物, 29, 379 (1991).

4) M. Usami, M. Satake, S. Ishida, A. Inoue, Y. Kan \& T. Yasumoto: J. Am. Chem. Soc., 117, 5389 (1995).

5) (a) Y. Hashimoto, N. Fusetani, S. Kimura : Bull. Jpn. Soc. Sci. Fish., 35, 1086 (1987) ; (b) T. Yasumoto, D. Yasumura, Y. Ohizumi, M. Takahashi, A.C. Alcala \& L. C. Alcala : Agric. Biol. Chem., 50, 163 (1986) ; (c) M. Fukui, M. Murata, A. Inoue, M. Gawel \& T. Yasumoto：Toxicon, 25, 1121 (1987) ; (d) 前田 満, 児玉 
亨, 田中隆治, 吉栖 肇, 野本亨資, 竹本常松, 藤田稔夫 :

“第 27 回天然有機化合物討論会講演要旨集”, 1985, p. 616 .

6) R. E. Moore, P. Helfrich \& G. M. L. Patterson : Oceanus, 25, 54 (1982).
7) H. Nakamura, T. Asari, A. Murai, Y.Kan, T. Kondo, K. Yoshida \& Y. Ohizumi : J. Am. Chem. Soc., 117, 550 (1995).

（佐竹真幸, 安元 健, 東北大学農学部)

\section{大腸菌におけるカタボライト抑制：cAMPドグマの 批判的検証}

ジオーキシーにおいてはリプレッサーが大きな役割. cAMPの新たな役割解明が課題

微生物において, 培地中のグルコースが他の炭素源の 代謝酵素の合成を抑制する現象はグルコース効果として 古くより知られている. グルコース以外の糖やそれらの 異化代謝産物（カタボライト） も類似の抑制効果を示す ことから,この現象は一般にカタボライト抑制と呼ばれ るようになった(1). 大腸菌に打けるカタボライト抑制 は，バクテリアの環境応答系の最も古典的な例である が，情報伝達系としてのカタボライト抑制についての理 解は驚くほどそしいのが実情であり，ようやく最近にな って cAMP 中心の古典モデルの見直しと本質的な理解 をめざす研究が進展し始めた。

グリセロール培地などで増殖する大腸菌のラクトース オペロン発現に対するグルコースの抑制作用を解析した 初期の研究により, 抑制は転写段階で起こり, ラクトー スリプレッサーとは独立していること（実験は過剩の誘 導物質存在下で行なわれた）が明らかになった(2). この ころから, リプレッサーの作用とは独立に存在するグル コース効果が狭い意味で「カタボライト抑制」と呼ばれ るようになり, 紛らわしいことに, この用語は二重の意 味で使われるようになった ${ }^{(2,3)}$. 本稿では, この狭義の 「カタボライト抑制」に括弧をつけ当初の定義と区別し たい.

グルコース培地中では cAMP レベルが一般に他の炭 素源と比べ低いこと，グルコース添加によるラクトース オペロンの発現抑制が培地に加えた cAMP により部分 的に解除されることなどから, cAMP が「カタボライト 抑制」を仲介するという古典的モデルが提唱された ${ }^{(2)}$. この研究の過程で, cAMP 受容タンパク質 (CRP) が 発見され，CRP-cAMP 複合体が転写活性化因子として 働くことが証明される。すなわち, cAMPレベルの低下 による転写活性化因子 CRP-cAMP 複合体の濃度低下
が「カタボライト抑制」であるといら考觉が広く定着す ることになった。しかしながら，この単純明快と思われ るモデルには次の問題点があっだ(4).

1） cAMP の添加で「カタボライト抑制」は部分的 にしか解除されない.

2）アデニレートシクラーゼを欠損し cAMP 非要求 性の CRP (CRP*) を産生する株（この株では cAMP が存在しない）において「カタボライト抑制」が観察さ れる。

筆者らは，グルコースは CRP レベルも下げること， この CRP レベルの低下は cAMP レベルの変化とほぼ 同程度に「カタボライト抑制」に寄与していることを明 らかにし，上記の問題に解答を与えた ${ }^{(5,6)}$. また，CRP レベルの低下は, CRP 遺伝子の自己制御機構に欠損が生 じると消失することから，グルコース作用の不可欠な要 素としての自己制御機構の意味が浮き彫りになった ${ }^{(7,8)}$. 一方, グルコースは, アデニレートシクラーゼの活性調 節により cAMP レベルを低下させると考劣られてお り，多くの単糖の取り込みを担らホスホエノールピルビ ン酸依存性糖輸送系 (PTS) がこの制御に関与している ことは確実であるが，その分子機構は不明である(9).

「カタボライト抑制」に和ける CRP レベル変動の役 割を明らかにした上記の研究は， cAMP ドグマのいわ ば穩便な修正といえる。 cAMP ドグマのより深刻な問 題点は, グルコース効果（したがって広い意味のカタボ ライト抑制）の最も有名な例であるジオーキシーの機構 に関して明らかになった. グルコースとラクトースが共 存すると, 菌はグルコースを優先的に代謝し，この間 クトースオペロンの発現は強く抑制される. グルコース 消費後しばらくして，菌はラクトースの代謝を始め， 2 段階の増殖曲線（ジオーキシー）、を示す： cAMP モデ 


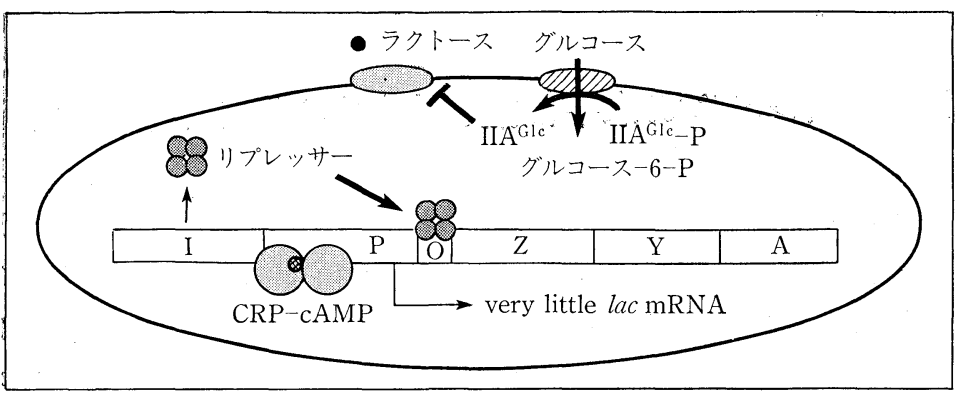

図 1・ラクトースオペロンにおけるグルコース効果の新しいモデル グルコースの細胞内への輸送とリン酸化に共役して脱りン酸化された IIAGlc が，ラ クトースの細胞内取り込みタンパク質の活性を阻害する. したがって, グルコースとラ クトースが共存する培地においては, ラクトースの細胞内への輸送が阻害され, ラクト 一スオペロンの転写はリプレッサーによりほぼ完全に抑制される. 一方, 正の転写因子 である $\mathrm{CRP} / \mathrm{cAMP}$ 量はラクトース単独の場合と同程度である.
際，筆者らはリプレッサー遺伝子ま たは IIAGIc 遺伝子を破壊するとグ ルコースの優先的代謝とラクトース オペロンの発現抑制は消失すること を示しこの仮説を証明した（図 1).マルトースやグリセロールに拉 けるグルコース効果においても，ラ クトースの場合と同様に, リプレッ サーによる負の調節機構が必須であ る結果も得ており,この機構がグル コース効果一般に重要な役割を果た しているようである.

本稿で筆者らが言いたいことは, ルの強い影響もあって, ジオーキシーに括けるラクトー スオペロンの発現抑制も cAMP レベル低下のためとい らドグマが広く浸透している.ところが驚くべきこと に, ジオーキシーに拈ける cAMP の濃度を実際に検討 した研究はなかった.つまり, ジオーキシーの機構に関 する限り cAMP モデルは推測の産物といらことになる. 筆者らは, ジオーキシー中の大腸菌の cAMP と CRP の濃度を初めて経時的に測定し、グルュース代謝時とラ クトース代謝時に沶いてこれらの量に医とんど差異がな いことを見いだした ${ }^{(10)}$.この結果は、ジオーキシーにお 壮るグルコース効果は cAMP レベルの低下によるとす るこれまでの “常識”と相容れない.ラクトース培地に おける cAMP と CRP の濃度は, グリセロールなど他 の多くの糖に比較したとき数倍低く，ラクトースオペロ ンの発現は最大レベルの $20 〜 30 \%$ 程度であるが, ラク トースの代謝にはこの程度の発現レベルで十分であると いうことになる.

グルコース効果については,「カタボライト抑制」と 性別に,グルニースの取り达みに関与するPTS のタン パク質の $1 つ$ IIAGlc が誘導物質（糖）の取り込みを阻 害する機構が誘導物質排除として知られている(9). グル コースの取り込みとリン酸化に共役して脱リン酸化され た IIAGlc が，誘導物質の細胞内取り込みを阻害すると いら機構である. CRP-cAMP レベルの変動が関与しな いなら，誘導物質排除によるリプレッサーの活性の上昇 こそジオーキシーの主因であることを予想させる，実
確立されたと考えられている学説を盲信することの危険 性であり，情報伝達因子，遺伝子発現調節因子として の cAMP の重要性を否定することではない。むしろ, いままで見過ごされてきた cAMP の役割を新たに検討 すべき時期と考えている，たとえば，注目すべきことに cAMP レベルはグルコース代謝からラクトース代謝へ 移行する増殖停止時に一過的に大きく上昇することを見 いだしている. この cAMP レベルの一過的上昇がラク トース代謝への速やかな移行に好都合であることは明ら かであるが，この点を含め, cAMP レベルの動的変化 の機構と生理的意義の解明は今後の重要な研究課題であ ろう.

1) B. Magasanik: Cold Spring Harbor Symp. Quant. Biol., 26, 249 (1961).

2) I. Pastan \& R.Perlman : Science, 169, 339 (1970).

3) B. Magasanik: in "The Lactose Operon", ed. by J. Beckwith and D.Zipser, Cold Spring Harbor Laboratory, New York, 1970, p. 189.

4) J. L. Botsford \& J. G. Harman : Microbiol. Rev., 56, 100 (1992).

5) H. Ishizuka, A. Hanamura, T. Kunimura \& H. Aiba : Mol. Microbiol., 10, 341 (1993).

6) H. Tagami, T. Inada, T. Kunimura \& H. Aiba : Mol. Microbiol., 17, 251 (1995).

7) A. Hanamura \& H. Aiba : Mol. Microbiol., 6, 2489 (1992).

8) H. Ishizuka, A. Hanamura, T. Inada \& H. Aiba : $E M B O$ J., 13, 3077 (1994).

9) P. W. Postma, J. W. Lengeler \& G. R. Jacobson : Microbiol. Rev., 57, 543 (1993).

10) T. Inada, K. Kimata \& H. Aiba : 投稿中.

（稲田利文, 㗽場弘二, 名古屋大学理学部分子生物 学科) 


\section{ウイルスが運ぶ(?)イントロン}

\section{藻類, 酵母, 原生動物間のグループI イントロンの水平伝播を仲介するクロレラウイルス の発見}

グループ I 自己スプライシングイントロンは, 酵素活 性を持つRNA（リボザイム）として初めて認識された ものである.すなわち, 特徴的な一次・二次構造をもつ 約 400 塩基ほどの RNA がイントロンとして存在し， グアノシンや $\mathrm{Mg}^{2+}$ の存在下で自らの触媒作用によっ て自分の切り出しと両端のエクソンの結合を行なうもの である.これまでに様々な原核生物ゲ/ム，下等真核生 物の核遺伝子，オルガネラ遺伝子などに多種（200 種以 上）見いだされているが，その存在は生物種間の系統的 関倸と相関性がまったくない，同じ生物種に扔いても株 によって存在はまちまちであるし，かと思うと，非常に よく似た構造のものがまったくかけ離れた生物種の同じ 遗伝子の同じ位置に見つかったりするのである.このこ とから，イントロンが生物界間（interkingdom）で水平 伝播する可能性が考兄られ(1)，その機構と生物学的意味 に大きな関心が寄せられてきた。

グループエイントロンの移動の分子機構として, 大き く(1)DNA レベルで起こるものと，(2)RNA レベルで起 こるものの $2 つ か ゙$ 提唱されている(2). 前者においては, 特殊な塩基配列特異的エンドヌクレアーゼ（I-制限酵 素), つまりホーミング (homing) 酵素が関与し, イン トロンのない遗伝子座の DNA に切断を入れ，遺伝子変 換によってイントロンが挿入される、ホーミング酵素は イントロン自身が保有する ORF にコードされている.

しかし，多くのイントロンは ORFをむたないし，ORF はそれ自体転移因子のように振舞ってイントロンに入っ たり出たりすると考えられている.

後者の機構においては，イントロンが内部ガイド配列 (IGS) に対合できる RNA 標的配列を認識して, スプラ イシングの逆反応，つまり逆スプライシング（reverse splicing）によって組及达まれる。皇して逆転写反応を 経て DNA へ插入される. 問題は, いずれの機構によっ ても,イントロンの移動に際し，イントロンとその標的 部位が “物理的に接触”しなければならない点にある。

たとえば，緑藻クロレラの核 SSU rRNA 遺伝子に見
いだされたイントロン（IB 型）は，カリ二肺炎病原体 Pneumocystis carinii（酵母の一種といわれている）のイ ントロンと非常に構造が似ておう，また特異的な挿入部 位も完全に一致している( ${ }^{(3)}$. 一方，クロレラのもう1つ の核 LSU rRNA イントロンの構造は原生動物テトラヒ ィナのものと、これまな驚くほどよく似ている。もし， これらのイントロンが起源的に同一であるとすると（と ても無関係とは思觉ない)，どのようにして“物理的接 触”が起こったのだろうか？ 藻類，酵母，原生動物の 三者間の系統的関係を考光た場合これはまったくの謎 である、唯一、もっともらしく考觉られる模式は，これ ら三者の間を渡り歩く物体 (ベクター) の存在であるら。 それはウイルス，あるいはウイルス様可動因子を和いて は考觉られない，最近，その有力な候補が見つかった。

自然界でクロレラは，多くの場合他の生物，特に原生 動物ゾウリムシや腔腸動物ヒドラなどと細胞内共生系を 営んでいる，その共生クロレラ（zoochlorella といら） に感染するウイルスが自然界より多数見いだされてい る(4,5). このウイルスは大型正二十面体粒子で，ゲノム として約 $350 \mathrm{~kb}$ の線状 ds DNA のゲノムを有する（図 1).ダノムの末端がへアピン構造をとっている点で， クシニアウイルスやアフリカ豚熱病ウイルス (ASFV) に似ている. ウイルスとしては異例に大きいゲノムは



図 1曰クロレラウイルスの電顕写真

T. Yamada et al.: Appl. Environ. Microbiol., 57, 3433 (1991)より 


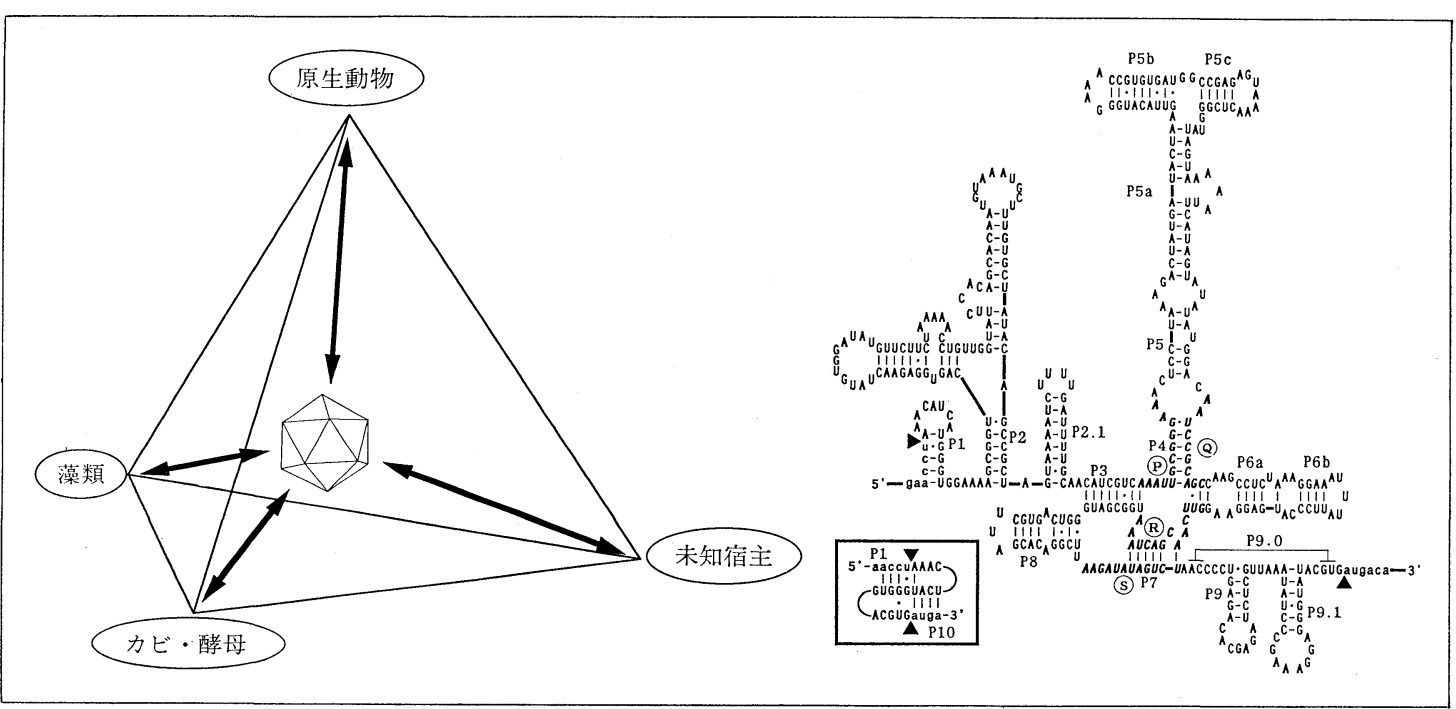

図 2ロウイルスを仲介因子としたグループI イントロンの水平伝播モデル

ウイルスは感染により宿主からイントロンを受け取り, 次の感染時に異なる宿主にイントロンを引き渡す. ウイルス宿主域の広さに応 じてイントロンの生物界間の水平伝播が可能となる. 右上にグループIイントロン（ウイルス起源）の構造を示す.

200〜300 もの 遺伝子をコードすることができ，どのよ らな遺伝子がコードされているかに非常に興味がもたれ る.

転写伸長因子 SII (TFIS) の遺伝子もとの 1 つであ った.この遺伝子上に 399 塩基より成る典型的な IB 型グループI 自己スプライシングイントロンが見つか っだ(6). 期待どおり, RNA 一次・二次構造とも, これま で知られているイントロンと高い相同性を示した. この イントロンの移動性を示す証拠として, よく似たイント ロンが別のウイルス株では別の遺伝子 (URF) に組み込 まれていることもわかった.ここに，このウイルスによ って藻類と原生動物との接点が生じた. さらに興味深い ことに, このウイルスはどうやら酵母やカビとも因縁が 深いらしい. ウイルス TF II S 遺伝子の一次配列自体は どんな生物よりも酵母のものと最も相同性が高いので ある. このことは, 他の複数の遺伝子解析の結果によ っても支持された. とりわけ，タンパク質合成伸長因子 EF-3 は酵母, カビ, 原生動物などに特異的な因子であ るが, この遺伝子がウイルスにコードされて和り, 感染 サイクル中に発現している事実 ${ }^{(7)}$ は, このウイルスの宿 主域がこれら生物にも及ぶことを示唆している.

ウイルスの広宿主域性を暗示させるもら一つの事実
は, 徐々に明らかになってくるウイルス遺伝子種の中に 遺伝子ファミリーが少なからず見られる点にある. たと えば，外殼タンパク質遺伝子は少しずつ異なるものが複 数個存在しこれらの組み合わせによって“着せ替えウ イルス”が形成される可能性がある.つまり, 宿主細胞 への親和性に幅をもたせていると思える.

このウイルスを仲介役と考えると, 各種藻類, 酵母, カビ, 原生動物など（グループ I イントロンは主として これら生物に見られる）が物理的に結びつき，イントロ ンの水平伝播をよく説明できる（図 2). すなわち, ウイ ルスは感染によって宿主遺伝子のもつイントロンを受け 取り, 次の感染の際にはそのイントロンを新しい宿主に 引き渡すといら構図が浮かんでくる. ウイルスの宿主域 の広さに応じてイントロンは生物界間 (interkingdom) に水平伝播することになる，この考劣を支持するかのよ らに, ここ $2 \sim 3$ 年の間に, クロレラ各種をはじめ, 緑 藻, 紅藻, 車軸藻などの藻類に非常に多く類似グループ Iイントロンが見いだされるよらになった.これらイン トロン配列間の分子系統樹を詳しく検討し相互の関係を 明らかにすることが重要である. かれこれ 15 年前の発 見以来, グループ I イントロン（特に IB 型）は, その “宿主”テトラヒメナとのイメージの重なりが強かった 
がここに来て認識が大きく変わりつつある.

1) A. M. Lambowitz \& M. Belfort : Annu. Rev. Biochem., 62, 587 (1993).

2) M. Belfort: Science, 262, 1009 (1993).

3) T. Aimi, T. Yamada \& Y. Murooka : Gene, 139, 65 (1994).

4）山田 隆 : 蛋白質核酸酵素, 37, 2161 (1992).
5）山田 隆: “ウイルスによるクロレラの殺滅”, 石田祐三郎・菅 原 庸編, 水産学シリーズ No. 99, 恒星社厚生閣, 1994, p.97.

6) T. Yamada, K. Tamura, T. Aimi \& P. Songsri : Nucleic Acids Res., 22, 2532 (1994).

7) T. Yamada, T. Fukuda, K. Tamura, S. Furukawa \& P. Songsri : Virology, 197, 742 (1993).

\section{魚類はよ゙のように活性酸素のストレスから身を守って いるのか}

\section{酵素的防御能と皮膚のユニークなスーパーオキシドジスムターゼ}

地球の大気に 酸素が出現しその濃度が上昇するにつ れ, 生物は酸素ストレスに対する防御能を身につ酸素 の“毒性”を克服した.そして，呼吸することで酸素を逆 に利用し, 効率的にエネルギーを生産して進化の道を歩 んできた ${ }^{(1,2)}$. 本来は安定な物質である酸素（三重項酸 素, $\left.{ }^{3} \mathrm{O}_{2}\right)$ は, 生体の内・外に打ける種々の反応により, スーパーオキシド $\left(\mathrm{O}_{2}^{-}\right), \mathrm{H}_{2} \mathrm{O}_{2}, \quad$ ヒドロキシラジカル $(・ \mathrm{OH})$ 护よび一重項酸素 $\left({ }^{1} \mathrm{O}_{2}\right)$ などの非常に反応性の 高い活性酸素に変化する(2). これら活性酸素は善と亜の 両面を有して和り, 実に様々な生命現象 (生体防御, 組織 障害, 種々の疾病の発症と進行抏よび老化など）に関係 しているといわれ，本誌でもたびたび取り上げられてい る.すなわち, この世の生命現象の多くは, 酸素の利用 之酸素障害に対する防御の上に成立しているといえる.

生体が有する抗酸化防御能には, 後述する酵素的なも のとトコフェロールやグルタチオンなどに代表される非 酵素的なものが知られている(2). スーパーオキシドジス ムターゼ (SOD), カタラーゼ拉よびグルタチオンペル オキシダーゼ (GPx) は, 酵素的防御能の代表的な抗酸 化酵素であり, それぞれが $\mathrm{O}_{2}^{-}, \mathrm{H}_{2} \mathrm{O}_{2}$, あるいは過酸化 脂質などの活性酸素を分解・消去している. 残念なが ら一生体に和ける活性酸素やそれに対する防御能に関す る従来の研究は，主として陸上生物を対象になされてお り，水圈生物についての知見は十分とはいえない，たと えば，魚類は体内に多量の高度不飽和脂肪酸を含有し， 脂質過酸化を受ける危険性が非常に高い。また，体外は 污染物質などと常に接している. にもかかわらず, 彼ら は簡単に病気に陥ることもなく, 元気に暮らしている. これは魚類が何か特殊な防御能を有しているためなので

\section{あろうか。}

筆者らは，まず手始めに，入手が容易で馴染み深いコ イを用い，その肝すい臓の GPx を調べてみた(3). その 結果, 性状の異なる 2 種類の GPx の存在が明らかとな った，その比活性は，他の魚類組織のそれをかなり上回 って拈り(4), コイの寿命が長いことや，病気や環境の変 化にも比較的強いこととの関連性がうかがわれる。

次いで, 筋肉の GPx について, その活性の消長を 4 ${ }^{\circ} \mathrm{C}$ および凍結貯蔵下で測定したところ，いずれの温度で も日数の経過とともに活性が増大することを認めた(4). また，笳肉 GPx は，酵素反応の基質であるグルタチオ ンを添加することでその安定性が向上すること，逆に数 種の活性酸素により活性が低下することも見いだした. すなわち，筋肉中の GPx を安定化しその機能を発揮さ せることで，貯蔵時の脂質過酸化などに起因する品質の 低下を防止できる可能性が示唆された.

筆者らは次に，魚類組織の中では酸化的ストレスを最 も受け易い組織の一つである皮膚に着目した。ヒラメほ ど極端ではなくとも，多くの魚類の皮膚には黒っぽい部 分と白っぽい部分が存在している. そこで, 抗酸化酵素 系の第一ステップに働くSOD の活性を，この魚類皮膚 の黒色部と白色部について測定してみた，真核生物の SOD には，酵素の活性中心に存在する金属の種類によ り $\mathrm{Cu}, \mathrm{Zn}$-SOD 执よび Mn-SOD の 2 種類が知られて いるが，魚類皮膚ではいずれの SOD 活性も黒色部のほ らが白色部よりも高かった ${ }^{(5)}$. 皮膚黑色部にはメラノフ オアが含まれており，そこではメラニンが盛んに合成さ れている(6). このメラニンの合成は活性酸素, 特に $\mathrm{O}_{2}^{-}$ により促進されるといわれて和り(7)，魚類皮膚の SOD 
活性について認められた結果と考え合わせると，SOD が皮膚に打けるメラニンの合成に深く関係していること が予想される.

陸上動物も含め，皮虐 SOD を精製，単離した報告は ほとえど知られていないが，筆者らはヒラメ皮䖉黒色部 より $\mathrm{Cu}, \mathrm{Zn}-\mathrm{SOD}$ を精製することに成功し，その SOD のニニークな性質を明らかにすることができだ ${ }^{(8)}$. 従来 の報告によると，他の生物種に由来する $\mathrm{Cu}, \mathrm{Zn}-\mathrm{SOD}$, たと衤ばウシ赤血球のそれはサブニニット 2 個からなる 2 量体で存在しているのに対し, 精製皮膚 SOD はサブ ユニット 4 個からなる 4 量体構造をとっている. さらに 面白いことに，既往の報告(9) とは異なり，サブニニット 間の解離には還元剤をまったく必要としない。また,一 般に $\mathrm{Cu}, \mathrm{Zn}-\mathrm{SOD}$ は非常に安定な三次元の立体構造を持 ち，高い耐熱性を有することが知られている(10)が，皮膚 SOD の耐熱性は著しく低い。アミノ酸組成を見てみる そ，疎水性のアミノ酸が少なく，その代わり極性の強い アミノ酸が多い，したがって，この SOD の耐熱性の欠 如は, 酵素タンパク質の蹯水性の低さに由来し, 恐らく タンパク質分子に拈ける非共有結合の位置や種類などる 影響して，結果的に分子の柔軟性が減少しているためと 考兄られる. しかし, この点に関しては, 立体構造も含 めさらに詳細な検討が必要であらう。一方, ウシ赤血球 SOD に対する抗体を用いた実験によると，皮虐 SOD はウシのそれとは免疫化学的性質が一致せず，皮䖉 SOD の抗原認識部位はウシのそれとは異なることが示 唆される(11).
以上, 魚類の活性酸素に対する酵素的な防御能を紹介 した. 魚類以外の水圈生物として, 最近, 筆者らが海藻 のカタラーゼを精製しその性状を検討したところでは, 陸上植物のそれとは多少異なったデータが得られてい る(12). また, 水圏の無脊椎動物であるウニやマガキにお いてもとの生体防御における活性酸素の重要性が示され ている(13,14). さらに対象水圏生物の種を広げることによ り, 水圈の生命現象における活性酸素の働きが解明され ていくことが期待される.

1） C. セーガン，A. ドルーヤン：“はるかな記憶（上），朝 日新聞社, 1994, p. 217.

2) 浅田浩二 : 蛋白質 核酸酵素, 33，7 (1988).

3) T. Nakano, M. Sato \& M. Takeuchi : Comp. Biochem. Physiol., 102 B, 31 (1992).

4) T. Nakano, M. Sato \& M. Takeuchi : J. Food Sci., 57, 1116 (1992).

5) T. Nakano, M. Sato \& M. Takeuchi : J. Fish Biol. (London), 43, 492 (1993).

6) 松本二郎：遺伝, 44, 31 (1990).

7) 大柳善彦：フレグランス・ジャーナル，18，94 (1990).

8) T. Nakano, M. Sato \& M. Takeuchi : FEBS Lett., 360, 197 (1995).

9) I. Fridovich : Ann. Rev. Biochem., 44, 147 (1975).

10) J. A. Tainer, E. D. Getzoff, K. M. Beem, J. S. Richardson \& D. C. Richardson : J. Mol. Biol., 160, 181 (1982).

11) 中野俊樹: 平成 6 年度文部省科学研究費補助金（桨励研究 A) 研究成果報告書 (1995).

12) T. Nakano, M. Watanabe, M. Sato \& M. Takeuchi : Plant Sci., 104, 127 (1995).

13) T. Ito, T. Matsutani, K. Mori \& T. Nomura : Dev. Comp. Immunol., 16, 287 (1992).

14) K. Takahashi, T. Akaike, K. Sato, K. Mori \& H. Maeda : Comp. Biochem. Physiol., 105 B, 35 (1993).

(中野俊樹, 東北大学農学部)

\section{耐塩性酵母Pichia farinosaの生産するキラー因子 酵母の認識機構, レセプターの解明が急務}

ある種の酵母はタンパク質性のキラー因子を分泌して 他の酵母の生育を阻害する. これまでに十数種のキラー 遺伝子がクローニングされるに至って, キラー因子と一 口に言っても, 一次構造, サブニニット構造, 性質, 機 能, あるいは遺伝子の所在などが異なる多様なタンパク 質の総称であることが明らかになってきた. 酵母の生存 に必須な部位を阻害して致死作用を示すキラー因子は, 生命現象を分子レベルで解明するためのプローブになり
らる可能性を持っている. たとえば, キラー因子のいく つかは, $\beta(1 \rightarrow 6)$ グルカン, マンナンタンパク, キチン などの酵母細胞壁成分をレセプターとして認識するた め，この性質を利用して酵母の細胞壁合成系の研究が多 方面から進められている ${ }^{1 \sim 3)}$.

筆者らは，味噌船から分離した耐塩性キラー酵母 $P i$ chia farinosa の生産するキラー因子について解析を進 めている(4)。このキラー因子は高濃度食塩存在下でより 
強いキラー活性を示すため, SMKT (salt mediated killer toxin) と命 名した. SMKTは $\alpha$ (63アミノ酸) と $\beta(77$ アミノ酸) の 2 つのサブュ ニットからなる分子量 1 万 4 千のタ ンパク質で, 222 アミノ酸からなる 前駆体として染色体上の遺伝子にコ ードされている. 遺伝子上にはシグ ナル配列， $\alpha$ サブニニット，中間配 列の $\gamma$ ペプチド， $\beta$ サブユニットの 順に並んでいる. $\alpha$ サブュニットの $\mathrm{C}$ 末端は 2 残基の塩基性アミノ酸の N末端側で終わっていることから， 塩基性アミノ酸を認識してその C末 端側で切断するエンドペプチダーゼ (Kex $2 \mathrm{p})$, 抢よび C 末端の塩基性 アミノ酸を取り除くカルボキシペプ チダーゼ（Kex1 p) の働きにより プロセシングされると推測できる. このプロセシング機構は酵母で見い

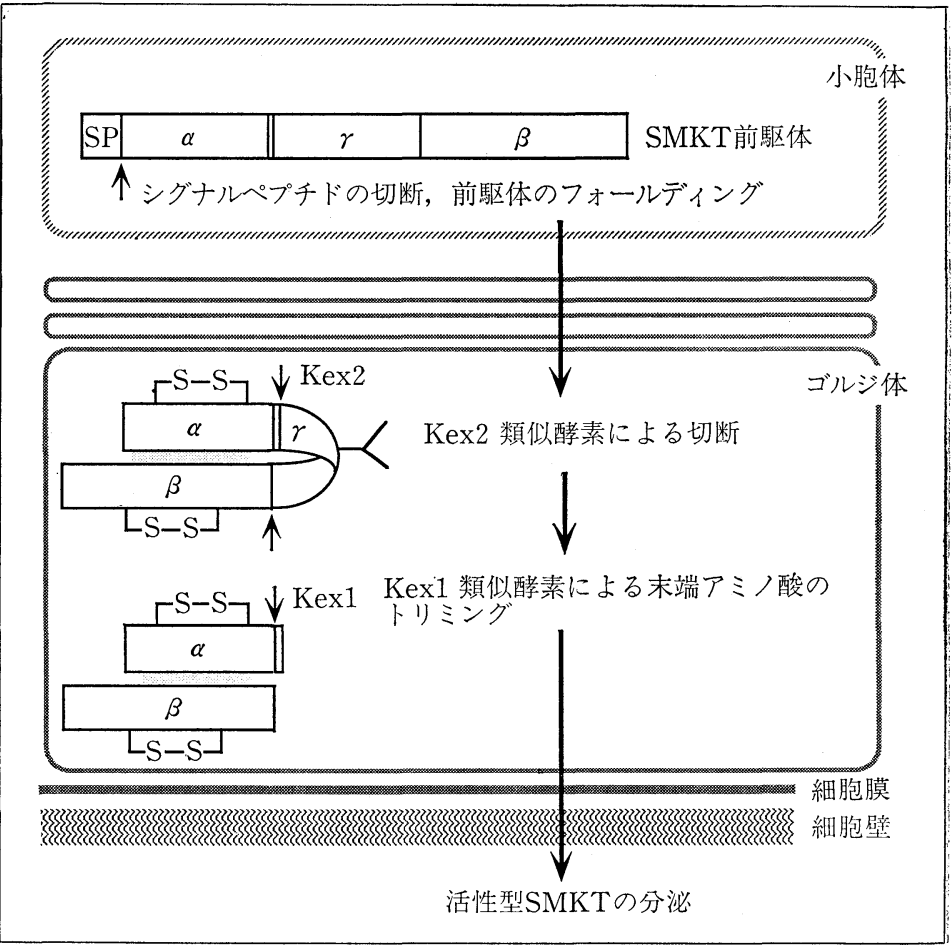

図 1 "耐塩性酵母 P. farinosa の生産するキラー因子 SMKT の分泌の模式図
だされ，真核生物に普遍的なものとされている。抢そら くSMKT 前駆体は小胞体でフォールディングを受けて $\alpha$ サブニニットと $\beta$ サブニニットの立体構造が形成され た後、ゴルジ体でプロセシングされ， $\gamma$ ペプチドが切り 放されて分泌されるものと考兄られる（図 1).

SMKT の前駆体構造および蹯水性度の分布は, S. cerevisiae の K 1 トキシンに類似がみられる. 遺伝子が RNA プラスミド上にある K 1 トキシンと, 染色体上に ある SMKT の前駆体が, 一次構造上の類似はないもの の, 類似のプロセシング過程を経て $\alpha$ とからなるキラ 一因子として分泌されることは興味深い、(5)，K1 トキシ ンは酵母細胞壁の $\beta(1 \rightarrow 6)$ グルカンをレセプターとして 認識する．K1 トキシンに耐性を示す変異株は $\beta(1 \rightarrow 6)$ グルカンに欠損あるいは異常がある表現型を示す。すな わち，変異株ではレセプターである $\beta(1 \rightarrow 6)$ グルカンが ないために K 1 トキシンが結合できず，キラー活性を 発現できない(1). SMKT が S. cerevisiae に対しても致 死作用を示すことを利用して，これらの K 1 トキシン 耐性変異株に対する SMKT の作用を調べた結果, キ
ラー活性が認められた．この結果から， SMKT の作用 に $\beta(1 \rightarrow 6)$ グルカンは必要なく, SMKT は少なくとも 感受性酵母の認識機構において K 1 トキシンとは異な る作用を持つと考兄られる. SMKT に対する耐性変異 株は, 遺伝解析の結果, 1 遺伝子の劣性変異であり, K 1 トキシンの耐性変異株とは異なる変異であった. これを相補する遺伝子を検索することによりレセプタ 一あるいは直接のターゲットの遺伝子が得られるのでは ないか， と期待しつつ解析を進めている.

SMKT のサブニニット間にはジスルフィド結合はな く，イオン結合あるいは疎水結合により相互作用してい るものと思われる. 活性は $\mathrm{pH} 4.5$ 以下では安定であ るが，pH 5 以上になると急激に失われる。たたたま， 失活した SMKT を得るため比較的高濃度 $(10 \mu \mathrm{M}$ 程 度) の SMKT 溶液を $\mathrm{pH} 6$ 以上に調製したところ, 溶 液が白濁することに気がついた，遠心後，沈殿と上清を 電気泳動してみると，沈殿には $\alpha$ サブュニット，上清に は $\beta$ サブニニットのみが含まれていた， $\alpha$ サブニニット は逆相 HPLC 上アセトニトリル濃度 $53 \%$ で溶出する 
非常に疎水性の高いペプチドであり， $\beta$ サブニニットと の解離により凝集し不溶化するものと思われる．逆にい えば， $\alpha$ サブュニットは $\beta$ サブニニットとの結合を介し て水溶性の性質を保持していると考えられる.

このように, SMKT の pH 変化による失活はサブュ ニットの解離に起因すると思われるが，この急激な構造 変化はどのようなメカニズムで起こるのだろらか. ま た，疎水性の高い $\alpha$ サブュニットがどのような形で $\beta$ サ ブユニットと相互作用し，水溶性のキラー因子としての 構造をとるのだろらか. プロセシングにより切り離され
る $\gamma$ ペプチドの役割も含めて, 前駆体のフォールディン グ過程にも興味が持たれる. 現在, この SMKT の構造 およびその構造変化についての解析を進めている.

1) J. Brown, Z. Kossaczka, B. Jiang \& H. Bussey : Genetics, 133, 837 (1993).

2) S. Kawamoto, M. Nomura \& T. Ohno: J. Ferment. Bioeng., 74, 199 (1992).

3) 中島 佑: 化学亡生物, 33, 146 (1995).

4) C. Suzuki \& S. Nikkuni : J. Biol. Chem., 269, 3041 (1994).

5) H.Zhu, H. Bussey, D. Y. Thomas, J. Gagnon \& A. W. Bell : J. Biol. Chem., 262, 10728 (1987).

（鈴木千セ，農林水産省食品総合研究所）

\section{EPAとDHA一ごちらがより有効か?}

\section{組織, 生理作用の違いによって特異性に差異. 軍配はDHA}

$n-3$ 系多価不飽和脂肪酸 ( $n-3$ PUFA) であるエイコサ ペンタエタン酸 (EPA) やドコサヘキサエン酸 (DHA) は海産魚油やアザラシなどの海獣油に含まれ，人の健康 に資する生理作用を持つことで最近最も注目されている 脂肪酸である(1). 特に DHA を食べると頭が良くなる （?）というのは, 真偽は別として子供でも知っている. ここでは，実験動物で得られた EPA と DHA の効果 の違いをPUFA およびェイコサノイド代謝への影響を 中心に述べる.

1970 年代に公表された疫学調査によると, グリーン ランドに住むイヌイット (エスキモー) はデンマーク人 に比べ血漿コレステロール濃度が低く，心筋梗塞などの 動脈硬化性心疾患や, 乾癬症, 気管支喘息などのアレル ギー疾患がきわめて少ない.デンマークに移住したイヌ イットでは, デンマーク人と同様の疾病をひき起こすこ とから，遺伝的因子が原因とは考兄られない.デンマー ク人は陸生動物脂肪，すなわら飽和脂肪酸の摂取量が多 く、また PUFA としては主に $n-6$ 系のリノール酸を摂 取しており，EPA や DHA を多量に含むアザラシを多 食するイヌイットとは対照的であったことから，EPA や DHA が一躍注目を集めることとなった(2).

日本人が摂取している PUFA は植物油に多く含まれ るリノール酸が最も多い. リノール酸は生体内で, 図 1 に示す一連の酵素によりジホモ $\gamma$ リリノレン酸やアラキ ドン酸へ代謝され，生体膜リン脂質の 2 位へ蓄えられる
が, 何らかの刺激に伴い切り出され, 多様な生理作用を 有するエイコサノイドの基質となる. 一方, $n$-3 PUFA である植物性の $\alpha$-リノレン酸は同じ酵素群で EPA と なり，別の系列のエイコサノイドへ転換される。また， EPA がさらに長鎖不飽和化されたものが DHA であ る. これら PUFA は, おもに(1)リン脂質の構成成分と して生体膜機能に関わり, また(2)エイコサノイドへ転換 されることにより必須脂肪酸の機能を発揮する.

リノール酸からアラキドン酸への転換の律速酵素は $\Delta 6$ 不飽和化酵素であるが，この酵素は $n-3$ PUFA によ り阻害され, 阻害効果は $\alpha-$ リノレン酸 $<\mathrm{EPA}<\mathrm{DHA}$ の順に強くなる. また, EPA やDHA はアラキドン酸 よりも生体膜リン脂質へ取り込まれやすいが，とくに DHA は顕著に取り达まれる. この 2 つの機構により, $\alpha-$ リノン酸や EPA に比べDHA は肝臓など多くの組 織のリン脂質中のアラキドン酸含量を最もよく減少させ $ろ^{(3,4)}$

アラキドン酸から合成されるエイコサノイドのうちト ロンボキサン $\mathrm{A}_{2}\left(\mathrm{TXA}_{2}\right)$ とプロスタグランジン $\mathrm{I}_{2}$ $\left(\mathrm{PGI}_{2}\right)$ は, 血栓症や心筇梗塞発症に密接に関わってい る.いくつかのエイコサノイド産生が，基質となるア ラキドン酸の量にかなり依存していることから， $n-3$ PUFA によるリン脂質中アラキドン酸の減少作用は, この PUFA 由来のエイコサノイド産生を減らす可能性 がある. 血小板でアラキドン酸から産生される $\mathrm{TXA}_{2}$ 


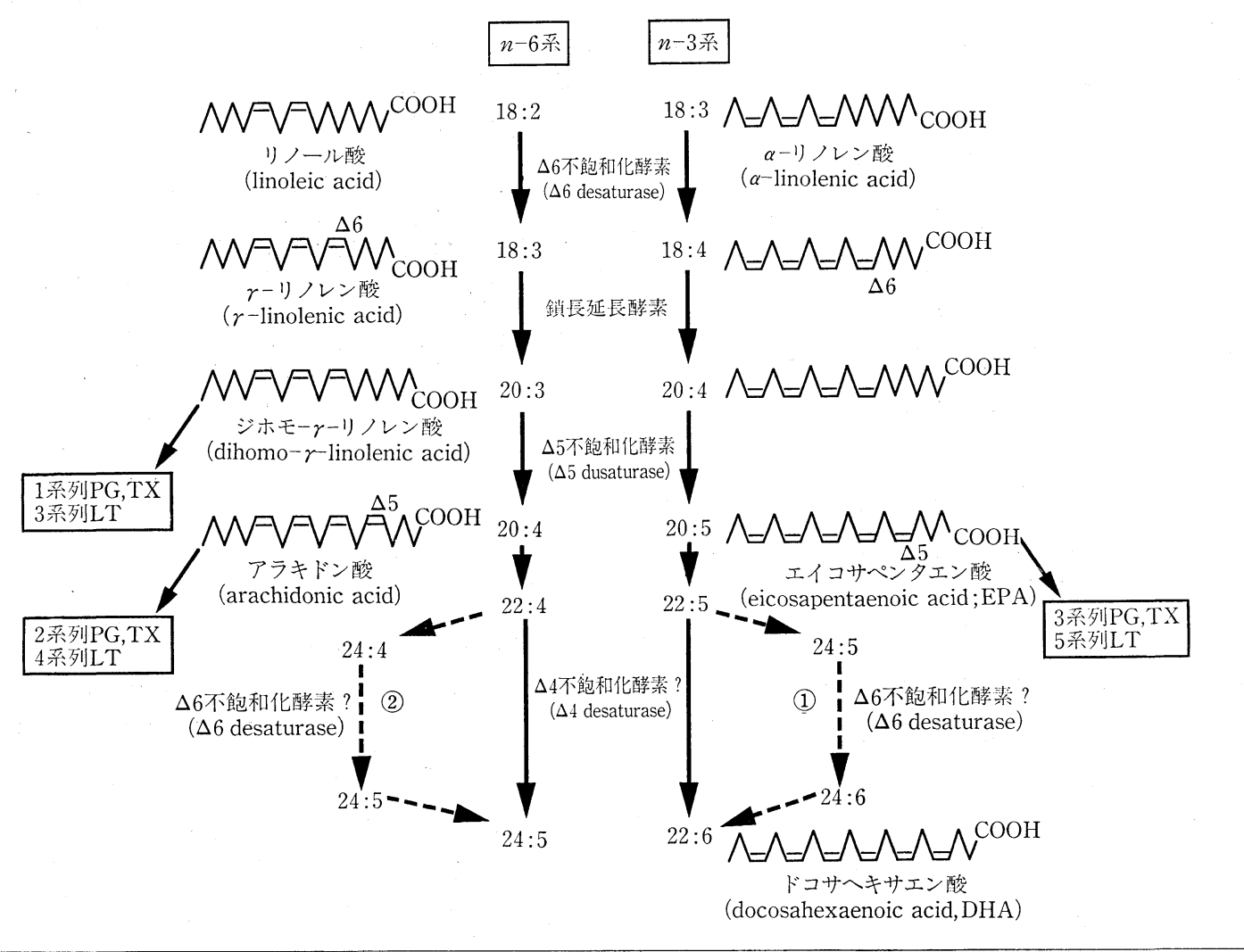

図 1 - 多価不飽和脂肪酸の構造と長鎖不飽和化反応およびエイコサノイド産生

EPA の DHA への不飽和化は $\Delta 4$ 不惧和化墰素で触媒されると考兄られてきたが，最近 Sprecher は別の経路を提唱した. EPA は炭素数 24 まで長鎖化された後， $\Delta 6$ 不飽和化酵素で不飽和化され，さらに $\beta$-酸化により炭素数 22 の DHA へ転換されるとい

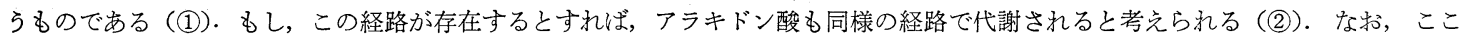
で作用する $\Delta 6$ 不飽和化酵素がリノール酸， $\alpha$-リノレン酸に作用する $\Delta 6$ 不館和化酵素と同一のものかどうかはまだ確証がない。 産生されるエイコサノイドの各系列は二重結合の数を表わしている.どのエイコサノイドが産生されるかは, 組織や器官によって決を っている.

$\mathrm{PG}$ : プロスタグランジン, $\mathrm{TX}:$ トロソボキサン, $\mathrm{LT}$ ：ロイコトリエン

はアラキドン酸量に依存する典型的なエイコサノイドで ある. $\mathrm{TXA}_{2}$ は血管を収縮し, 血小板を凝集させ, 生理 的には止血に大きな役割を果たすが，産生が兄進する と，血栓ひいては心筋梗塞をひき 起こす 原因となる。 n-3 PUFA の摂取によるリン脂質中のアアラキドン酸含 量の低下は, $\mathrm{TXA}_{2}$ 産生を抑制し,この効果は DHA で 最も強い(3).

一方, 大動脈壁で産生される $\mathrm{PGI}_{2}$ は $\mathrm{TXA}_{2}$ と拮抗的 に作用し，血管拡張おうよ゙血小板凝集抑制作用がある. 血管壁での $\mathrm{PGI}_{2}$ 産生は $n-3$ PUFA の影響を受けにく く,あまり変化しない、 ${ }^{(3,4)}$. この現象は, (1)血管壁のリソ
脂質のアラキドン酸は肝蔵や血小板ほどに減少しないこ そ，および(2) $\mathrm{PGI}_{2}$ 産生はリン脂質のアラキドン酸含量 に大きくは依存しないことによると考えられる.

このように, $n$-3 PUFA の効果には組織特異性があ り, 血小板 $\mathrm{TXA}_{2}$ 産生のみを減少させ, 心筋梗塞など 心疾患を防止していると考えられる. しかし，良いこと ばかりではない. EPA や DHA の多量㩒取により血小 板凝集抑制作用が充進すると，イヌイットにみられるよ うに脳出血などの出血性疾患が増加する.

な拉，ロイコトリエン（LT）はリンパ球から放出さ れアレルギー症状をひき起こすメディエーターの一種で 
あるが， $n$-3 PUFA の摂取はリンパ球リン脂質のアラキ ドン酸を減少させ， LT 産生を抑えることによりアレル ギー症状を軽減させると考えられる. アラキドン酸低 下作用の強い DHA は最も有効に作用する可能性があ る.しかし，アレルギー反応は複雑な過程を経て起こる ことから，DHA と EPA の作用の違いはまだはっきり とは証明されていない. LT 産生への効果以外にも $n-3$ PUFA のアレルギー応答に対する作用に関する報告は 多いが， ほとんどの場合，作用機構は解明されていな い.

イヌイットでは血漿コレステロールとトリグリセリド 濃度が低い，実験動物では EPA とDHA は同程度の血 漿トリグリセリド濃度低下作用を発揮するが，血漿コレ ステロール濃度は DHA でのみ低下する，この作用は肝 臓からのコレステロールやトリグリセリドを含むりポタ ンパク質 (VLDL) の放出抑制による可能性が高いが, DHA でのみコレステロールが低下する理由はよくわが っていない.

以上述べたよらに，DHA は EPA $\alpha$ リノレン酸よ りも強い生理作用を持つ. DHA はこのほかにも脳, 末 梢神経や網膜のリン脂質の構成脂肪酸として, 記憶学習 能や視力の向上などへの影響が示されつつある. $\alpha-1$ ノ
レン酸や EPA を摂取すると体内で DHA が生成する が，その転換効率は必ずしも高くない。これは， $\alpha$ リノ レン酸や EPA 自身が $\Delta 6$ 不飽和化酵素を阻害して, DHA への転換を抑えているためと推測される（図 1). したがって，DHA の有効性を高めるためにはDHA を 直接摂取するのが最も効率的である. しかし， EPA や DHA はきわめて強い生理作用を持つので，むやみに多 量摂取することには問題がある。また，これらの脂肪酸 が非常に過酸化されやすいことも摂取上注意しなければ ならない点である. 平均的日本人の恸取している $n-3$ PUFA は1日めたり約 $3.4 \mathrm{~g}$ ，そのうち $\alpha$ リリノレン酸 が $2 \mathrm{~g}$, EPA と DHA で $1.4 \mathrm{~g}$ 程度を占めている.い まのところ健康な人ではこの程度の摂取量が適切と判断 されて掞り，健康維持のためであれば，この数值を大き く上回る量の摂取は避けるべきであろう.

1）原一郎 (監修)：“油脂の栄養と疾病”，幸書房，1990。

2) 熊谷 朗: “EPA の医学”, 中山書店, 1994.

3) I. Ikeda, K. Wakamatsu, H. Yasunami, M. Sugano, K. Imaizumi \& K. Yazawa : "Advances in Polyunsaturated Fatty Acid Research", Elsevier Science Publishers, Amsterdam, 1993, p. 223.

4) I. Ikeda, K. Wakamatsu, A. Inayoshi, K. Imaizumi, M. Sugano \& K. Yazawa : J. Nutr., 124, 1898 (1994).

(池田郁男, 九州大学農学部)

\section{プロ ロ $11 \%$}

㗽場 弘二(Hiroji Aiba) 昭和 20 年 9 月15日生 $<$ 略歴 $>$ 昭和 43 年京都大学薬学 部製薬化学科卒業 /1974年同大学医学部 助手/1984年筑波 大学 化学系 助教授/ 1991年名古屋大学理学部教授, 現在にい たるく研究テーマと抱負 >遺伝子発現の 調節機構 $<$ 趣味 $>$ テニス，スキー

伊藤 文紀 (Fuminori Ito) 昭和39年 3 月 1 日生 $<$ 略歴 $>1986$ 年島根大学農学 部卒業／1992年北海道大学大学院環境科 学研究科修了/同年日本学術振興会特別 研究員／1993年香川大学教育学部助手／ 1995年同講師，現在にいたるく研究テー マと抱負>東南アジア産アリ類の生態と 社会構造, アリ類と他生物との相互作用 <趣味>映画観賞, 珊瑚礁でのシュノー ケリング, ビール
池田 郁男 (Ikuo lIkeda) 昭和 28 年 2 月 5 日生 $<$ 略歴 $>$ 昭和 50 年九州大学農学 部食糧化学工学科卒業 $/ 52$ 年同大学大学 院修士課 程修了 $/ 55$ 年 同博士 課程 修了 (農博) /同年 同農学部 栄養 化学 講座助 手/平成 2 年同助教授, 現在にいたる. この間，昭和59〜 61年米国ジョージワシ ントン大学健康・医学研究所研究員 $<$ 研 究テーマと抱負 $>$ 多価不飽和脂肪酸の生 理作用, 脂質吸収機構く趣味〉バドミン トン

稲田 利文 (Toshifumi Inada) 昭和 39 年 11 月 6 日生 $<$ 略歴 $>$ 昭和 62 年東京大 学理学部生物化学科卒業/平成 3 年日本 学術振興会特別研究員 $/ 4$ 年同大学大学 院理学系研究科生物化学専攻博士課程修 了(理博)/同年名古屋大学理学部分子生
物学科情報高分子学講座助手, 現在にい たるく研究テーマと抱負＞栄養源（主に 炭素源）の変動に応答した遺伝子発現制 御系の解析<趣味 $>$ 麻雀, 温泉, パン作 り

上田 岳彦 (Takehiko Ueda) 昭和 38 年 4 月 10 日生 <略歴 $>$ 昭和 62 年京都大学 工学部高分子化学科卒業/平成 5 年同大 学大学院博士課程修了/同年新技術事業 団超分子プロジェクトグループリーダ 一，現在にいたるく研究テーマと抱負> 人工境界脂質を用いたインスリンレセプ ター蛋白質の抽出とリポソームへの再構 成，膜蛋白質を含をりポソームを用いた 高次構造の構築＜趣味＞水泳之将祺 